Page 1 of $2 \quad \begin{aligned} & \text { Proj. } \\ & \text { ECN }\end{aligned}$

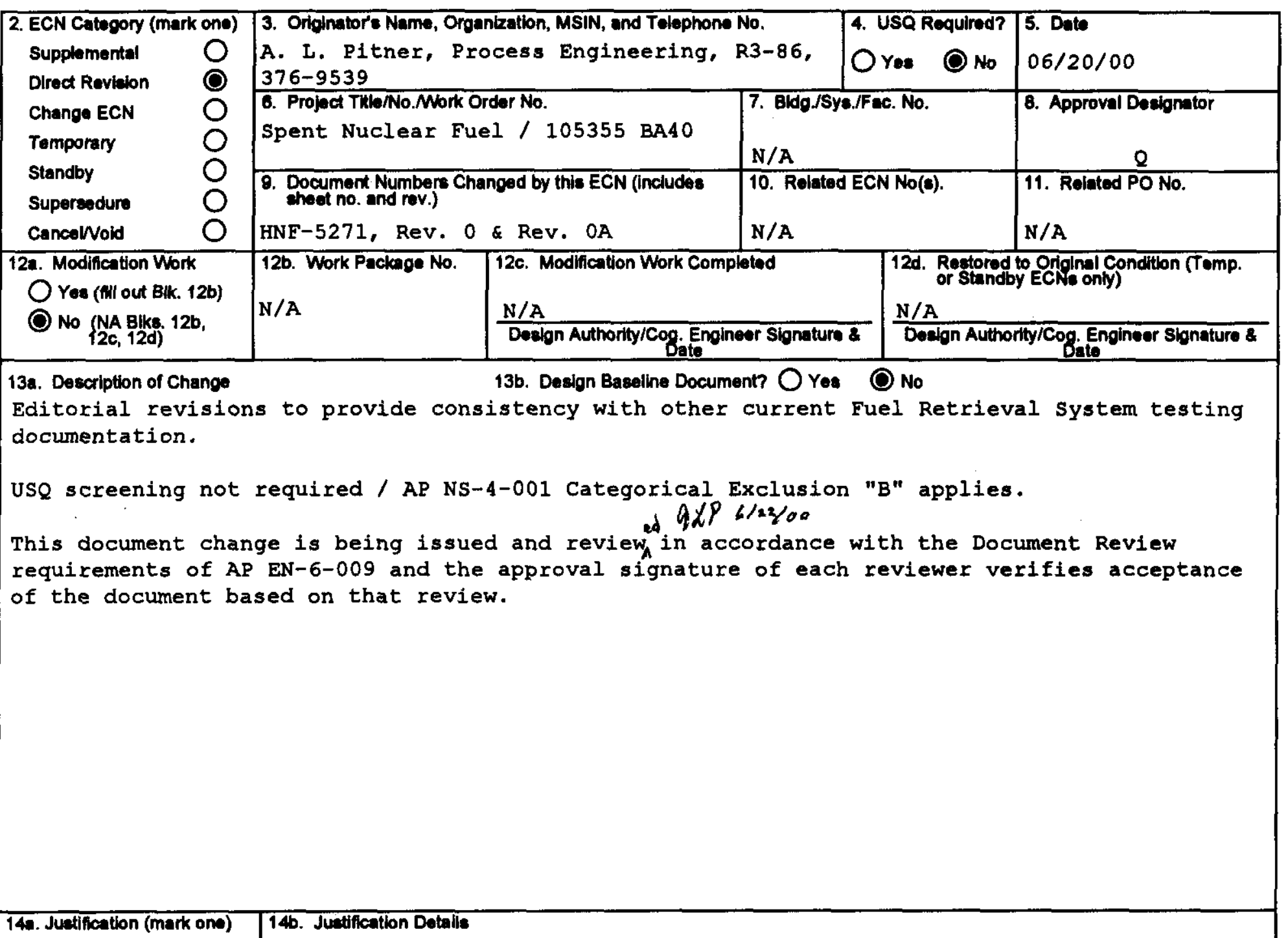

of the document based on that review.

Criteria Change Editorial changes

torial changes were made to make the document consistent with

Design improvement $O$ terminology used in other documents referenced in HNF-5271.

Environmental

Facility Deactivation

As-Found

0

Facilitate Const.

0

0

Const. Error/Omiseion

Design Error/Omiscion

15. Distribution (include name, MSIN, and no. of copies)

See Distribution sheet

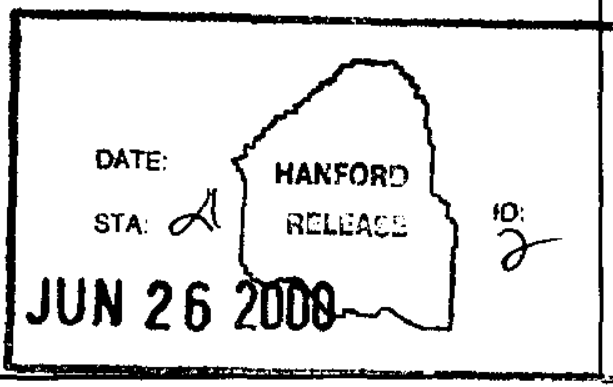




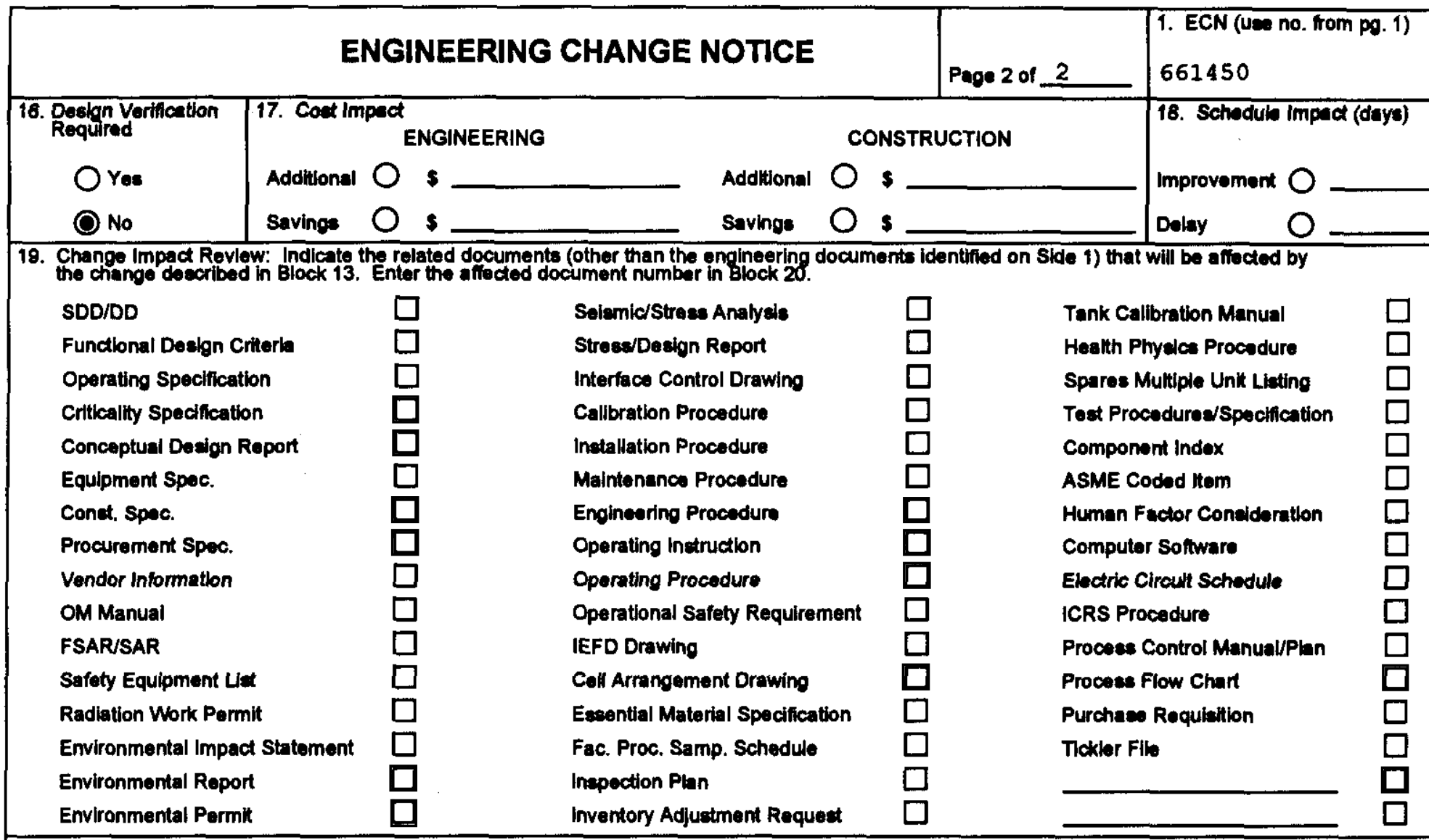

20. Other Affected Documents: (NOTE: Documents Histed below will not be rovised by this ECN.) Slonatures below indicate that the signing organization has been notified of other affected documents listed below.

Document Number/Revision Document Number/Revision

Document Number/Revision

$\mathrm{N} / \mathrm{A}$

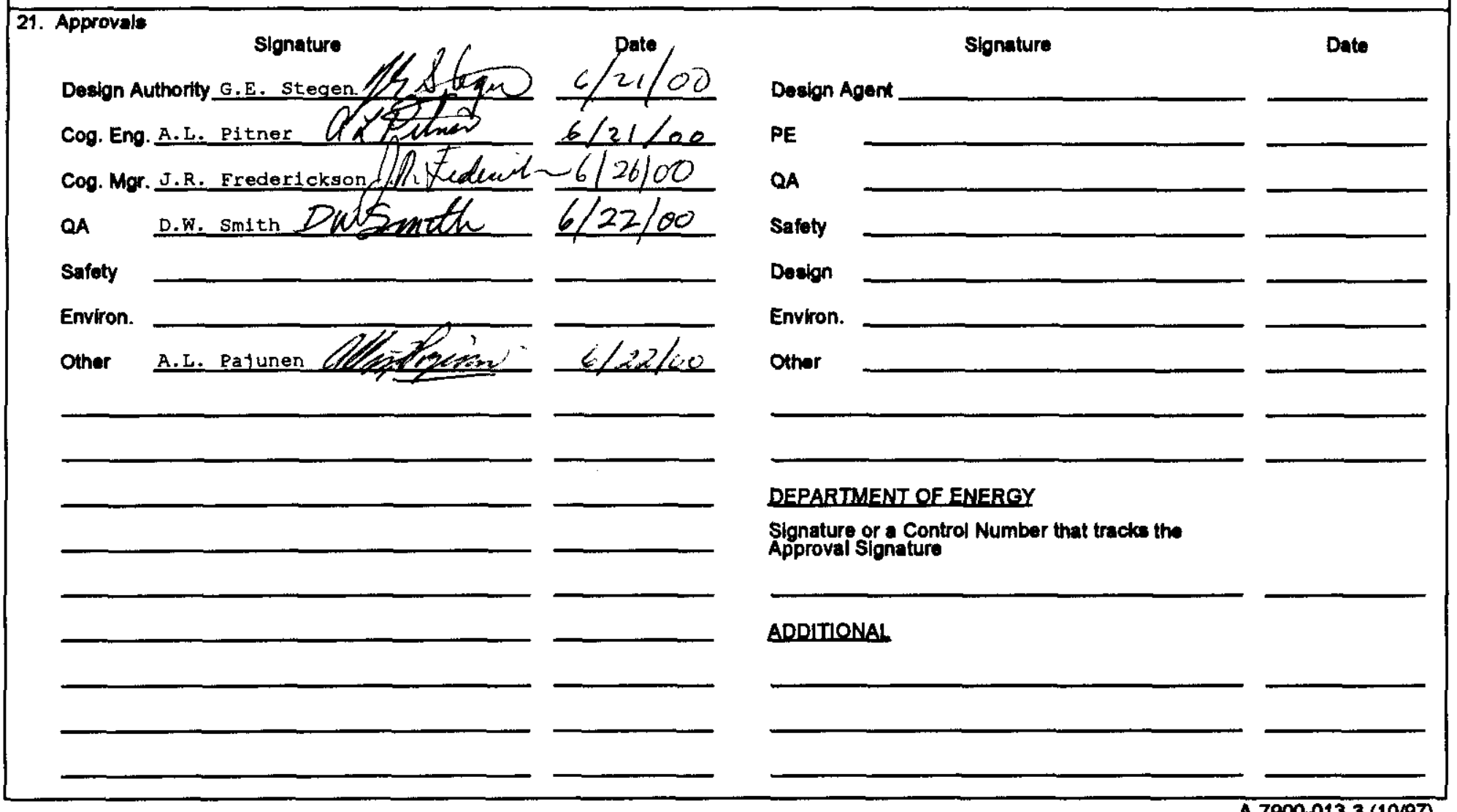


HNF-5271

Revision 1

\section{Planning Document for Spent Nuclear Fuel Cleanliness Inspection Process (OCRWM)}

Prepared for the U.S. Department of Energy

Assistant Secretary for Environmental Management

Project Hanford Management Contractor for the

U.S. Department of Energy under Contract DE-AC06-96RL13200

Fluor Hanford

P.0. Box 1000

Richland, Washington 


\title{
Planning Document for Spent Nuclear Fuel Cleanliness Inspection Process (OCRWM)
}

Division: SNF

\author{
A. L. Pitner \\ Fluor Hanford \\ Date Published \\ June 2000
}

Prepared for the U.S. Department of Energy

Assistant Secretary for Environmental Management

Project Hanford Management Contractor for the

U.S. Department of Energy under Contract DE-AC06-98RL13200

Fluor Hanford

P.O. Box 1000

Richland, Washington
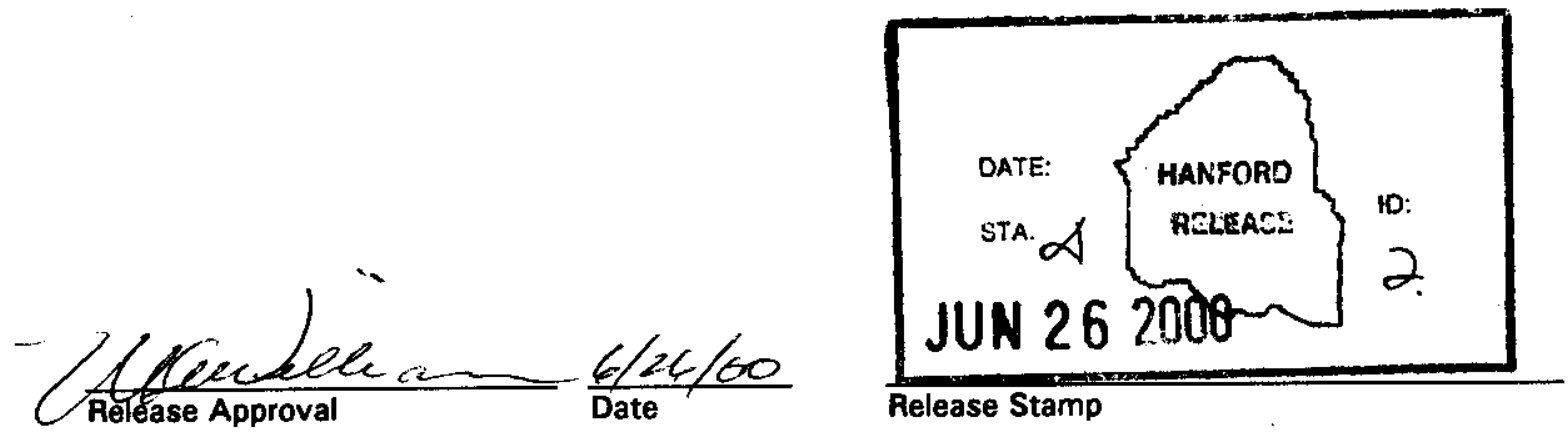
TRADEMARK DISCLAIMER

Reference herein to any specific commercial product, process,

or service by trade name, trademark, manufacturer, or

otherwise, does not neceesearly constitute or imply its

endoreement, recommendation, or favoring by the United

States Government or any egency thereof or its contractors or subcontractore.

This report has been reproduced from the best available copy. Avallable in paper copy and microfiche.

Available clectronically at http://uww.doe.gov/bridge. Available for a proceseing fee to the U.S. Department of Energy and its contractors, in paper, from:

U.S. Department of Energy

Office of Scientific and Technical Information

P.O. Box 62

Oak Ridge, TN 37831-0062

phone: 865-576-8401

fax: 865-576-5728

emall: reports Qadonls.cett.gov(423) 576-8401

Printed in the United Steten of America

Total Pages: 13

HNE-5271, new 
RECORD OF REVISION

(2) Title

Planning Document for Spent Nuclear Fuel Cleanliness Inspection Process (OCRWM)

Change Control Record

(3) Rovision

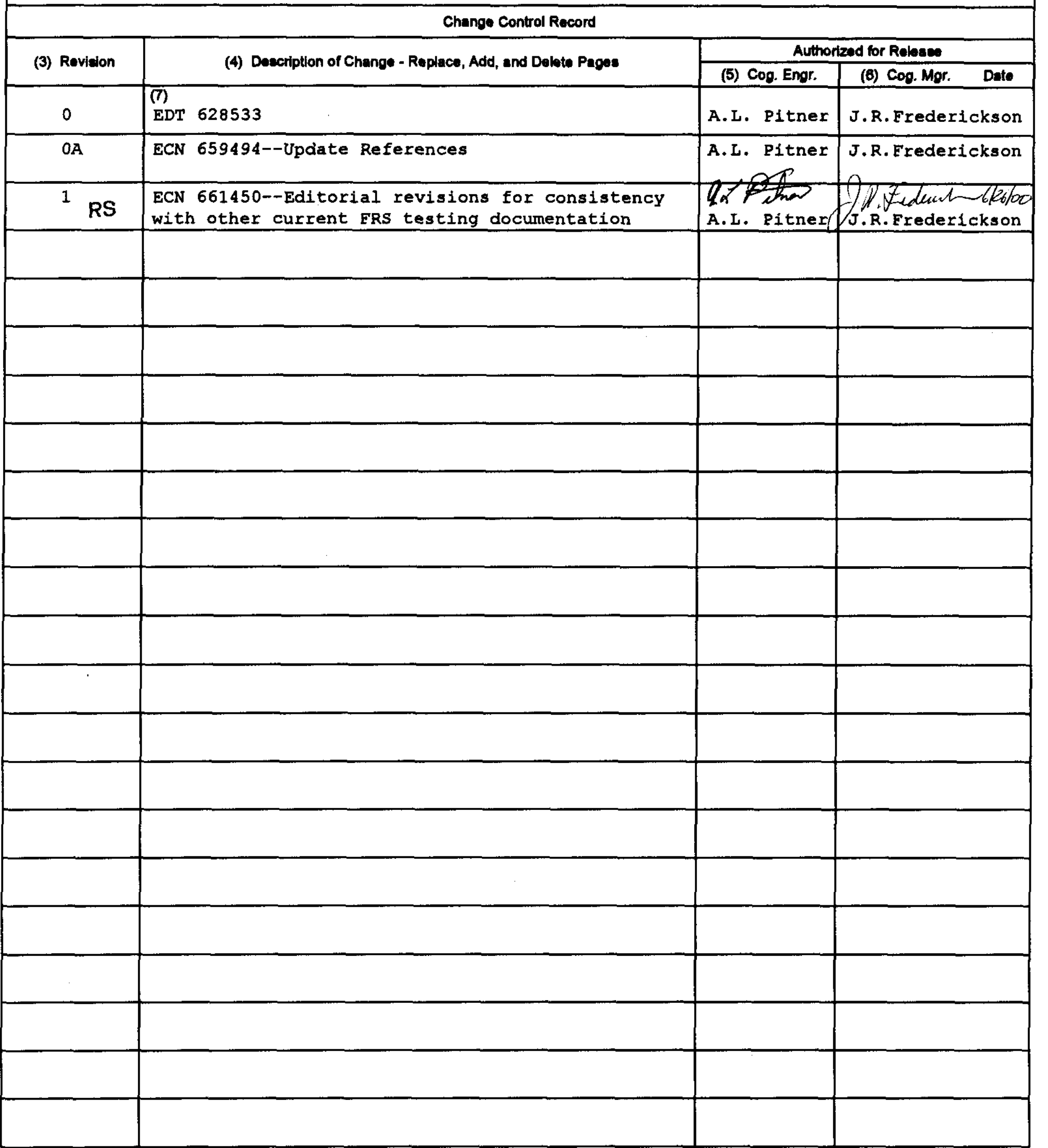

(1) Document Number

HNF-5271

Page 1 
HNF-5271, Rev. 1

\section{PLANNING DOCUMENT FOR SNF FUEL CLEANLINESS INSPECTION PROCESS} (OCRWM)

\subsection{OBJECTIVE}

The Fuel Retrieval System (FRS) Process Validation Procedure (Stegen 2000) requires that a specified quantity of fuel processed through the Primary Cleaning Machine (PCM) be inspected for cleanliness during initial operational and process validation testing. Specifically these inspections are performed to confirm that the PCM adequately cleans the fuel elements of canister sludge. The results of these inspections will be used to demonstrate that residual quantities of canister particulate on fuel elements loaded into Multi-Canister Overpacks (MCOs) are within projected levels used to establish safety basis limits (Sloughter 2000).

The fuel inspections performed as part of the validation process will be conducted during the Hot Operations portion of the Phased Startup Initiative (PSI) of the Fuel Retrieval and Integrated Water Treatment Systems (Pajunen 2000). Hot Operations testing constitutes Phases 3 and 4 of PSI. The fuel assemblies in all candidate canisters will be thoroughly inspected during these test phases (highly degraded fuel assemblies that qualify as scrap are exempt from inspection). During subsequent production operation of the FRS, only periodic inspections for cleanliness will be performed and documented.

This document describes the specific processes and techniques that will be applied in performing the cleanliness inspections, and the methodology used to verify that the documented inspection results conform to Office of Civilian Radioactive Waste Management (OCRWM) requirements. The procedures and processes presented here are in conformance with the Quality Assurance Program Plan for Implementation of the OCRWM Quality Assurance Requirements and Description (QARD) for the Spent Nuclear Fuel Project (QAPP-OCRWM-001).

\subsection{INSPECTION TEAM}

A select panel of four or five individuals with relevant experience disciplines will be assembled to perform the cleanliness inspections on the fuel elements during the process validation campaign. The inspection team members will have collective expertise in process engineering, characterization, operations, safety, or modeling. The panel will have completed training to satisfy basic process engineering requirements, and will be familiar with technical assumptions associated with fuel cleanliness.

In addition, a certified Quality Control Inspector will be present during cleanliness inspections to verify that recorded data are complete and correct. All personnel on the inspection team will be qualified to meet minimum requirements of the OCRWM QARD (DOE/RW/0333P). 
HNF-5271, Rev. 1

\subsection{INSPECTION CRITERIA}

The inner and outer surfaces of each disassembled fuel element will be examined to determine whether residual canister sludge after fuel cleaning exceeds allowable limits. Specifically, a fuel assembly would fail the cleaning criteria should either of the following conditions be found to exist after cleaning (Stegen 2000):

- Visual examinations identify a bore obstruction that cannot be attributed to features of the element (e.g., clad defects or clips) or coatings.

- When removing the inner element from the outer element, and/or during subsequent inspection of both elements, the total quantity of particulate matter (excluding coating material) observed is equivalent to or exceeds a cone that is 1 -inch in diameter at the base and 0.3 -inch high.

Figures 1 and 2 show nominal views of how such a cone-shaped pile would appear in relation to the size of a fuel assembly. The volume of this material is $1.3 \mathrm{~cm}^{3}$.

\subsection{INSPECTION PROCESS}

All inspection operations will be performed in conformance with approved procedures for conducting the FRS Phased Startup Hot Operations.

Cleanliness inspections of the fuel will be performed on a real time basis by the inspection team during conduct of the Hot Operations portion of the Phased Startup of the Fuel Retrieval System. At least three team members must be present to form an inspection team quorum. All inspection operations will be videotaped to provide video records for subsequent evaluation if needed.

The selected location for performing the inspections is the Equipment Operating Center (EOC). This allows for direct communication between the inspection team and operations personnel. These communications will be conducted between the EOC Operations Test Director and an appointed Engineering Test Director on the Inspection Team. This communication will be necessary to direct the positioning of fuel elements to achieve optimum viewing orientations, and to coordinate the collection of released sludge into an appropriate configuration for volume assessment. One member of the inspection team may be occasionally situated in the basin for overall observation of the cleaning and handling operations.

The inspection station shall be equipped with two VCRs for recording the cleaning inspection activities. Each VCR will be SVHS quality and have date-time stamp capability for imprinting the videotapes. Each VCR will have access (via a switcher) to any of four selected camera feeds from the EOC video distribution center. The inspection station will also be equipped with a computer connected to the HLAN. Signal feeds from the inspection station will be extended to the lunchroom for general audience viewing. 
Visual inspections of the fuel elements will commence once the fuel has been dumped from the canister onto the process table following cleaning in the PCM. Care should be exercised to maintain the assemblies intact during the dumping process; i.e., try to avoid separating the inner elements from the outer elements when dumping the canister contents on the table. However, even if the elements are inadvertently separated during the dumping process, they will still undergo inspection.

After dumping on the process table, the fuel assemblies will be individually transferred to the separation station for disassembly. Each separated fuel element will be visually examined for damage, consistent with damage categories previously employed in characterization assessments (Pitner 1998). The four damage categories are listed below. It is not anticipated that many (if any) fuel elements in the "Defected" category will be found after cleaning.

- Intact - No evidence of cladding rupture or end cap breach.

- Breached - Minor cladding rupture or end cap breach, but with no corroded fuel visible at the breach location.

- Defected - Definite evidence of cladding breach with reacted or corroded fuel present at the breach location. The amount of reacted fuel may be significant, but there is no gross cladding splitting, element dilation, or fuel voiding.

- Bad - Gross failure is evident with substantial element dilation, cladding splitting, breakage, or fuel voiding.

It is anticipated that "Bad" fuel elements will often be categorized as scrap destined for loading in MCO scrap baskets, and as such will not undergo inspection. Scrap is defined as fuel pieces less than 3 inches in their largest dimension, or as fuel elements with both ends ballooned such that neither end will fit into the go/no-go gauge. Fuel elements that do not qualify as scrap will be loaded into MCO fuel baskets, and will therefore undergo cleanliness inspection.

During assembly separation, the inner fuel element will be pushed from the outer element into a specially fabricated tray to facilitate collection of any canister sludge that may be dislodged during element separation (Figure 3). The collection tray shall be verified to be clean before each disassembly operation. The external surfaces of the separated elements will be visually examined for any residual canister particulate material. If possible, any such material should be physically dislodged and added to any inventory of particulate collected during element disassembly. Both elements will be turned vertically to permit any retained internal canister sludge particulate to drain into the collection tray. Care should be taken to preclude the inclusion of any aluminum hydroxide flakes in this inventory.

After removal of the inner assembly from the collection tray, the amount of sludge particulate present in the tray will be visually assessed. It is anticipated that in general this assessment will suffice to determine whether the $1.3-\mathrm{cm}^{3}$ limit has been exceeded. A secondary option is also available to the inspection team to assist in their evaluation of the sludge inventory. This involves temporarily attaching (slip fit) a special adapter to the tip of the secondary cleaning 
station vacuum wand (Figure 4), and suctioning the particulate material from the tray into the transparent known-volume chamber on the end of the adapter to help determine whether the $1.3-\mathrm{cm}^{3}$ volume limit has been exceeded. This adapter will be developed in laboratory testing (Pitner 2000), but is expected to be a semi-quantitative tool at best (all canister sludge may not be captured by the fine-mesh filter). The sludge collection adapter would be changed out after each use.

The bore of each disassembled fuel element will be examined using the available back-lighted fixture at the inspection station, and the observations compared to the inspection criteria described above (Section 3.0).

Based on the results of the above inspections, the fuel assembly will be judged to either pass or fail the cleanliness criteria. The damage level and results of the cleanliness inspection for each fuel element examined will be recorded on data sheets (Stegen 2000). During Phase 3 testing, fuel inspection team members will work as a group to determine the cleanliness of elements. This will provide experience for the inspection team with the actual assembly views available using FRS processing equipment. During Phase 4 testing, individual inspection team member cleanliness judgements will be recorded. The individual judgements will be compared at the conclusion of processing a canister. If disagreements are recorded between the individual observations, inspection videotape will be reviewed by the group to investigate the basis for differences. The results of this review, along with the consensus decision, will be recorded in the comment field of the inspection team data sheet.

\section{S.0 ACCEPTANCE VERIFICATION}

Phase 3 of PSI process validation testing consists of equipment operability verification. It is anticipated that at least six canisters of fuel will be processed during this phase of the testing to demonstrate satisfactory cleaning performance of the PCM. Some of the PCM operating parameters may be adjusted during this phase of the testing to improve or optimize PCM cleaning performance. This phase of testing will be considered complete when it has been demonstrated that the PCM satisfactorily cleans fuel from canisters that collectively contain fuel with the full range of damage categories. All fuel elements except "Bad" elements that qualify as scrap will be inspected during Phase 3 testing. The final PCM operating parameters established during Phase 3 testing will be applied to Phase 4 of the process validation program.

Phase 4 of PSI constitutes the actual process validation testing for the PCM. It will involve a minimum of 29 canisters of fuel selected on a random basis from the $K$ West Basin fuel inventory. Fuel inspection will again be performed on all but the "Bad" fuel elements that qualify as scrap during Phase 4 testing. Fuel cleaning operations will be considered successful if no more than one of the fuel assemblies in the 29-canister batch fails the cleanliness criteria. This provides $99 \%$ confidence that the worst case MCO (assuming the process continues to operate as validated) will be within bounding safety limits (Sloughter 2000).

If more than one fuel assembly in the 29 canisters tested fails the cleaning criteria, particulate and bound water calculations will be reviewed in light of new data available from the PSI Hot 
Operations test program. The first step will be to determine if available data provides adequate justification for modifying conservative assumptions used to calculate the canister particulate inventory. The bounding canister particulate associated with fuel will be recalculated based on actual failure frequency and the adjusted assumptions. If the revised calculation is within values presented in Sloughter (2000), qualification of the fuel cleaning process will be considered complete (Stegen 2000).

If the above assessment is not successful in demonstrating the particulate limit is met, then allowances for other particulate and bound water may be evaluated based on the new data available from PSI Hot Operations testing. If downward adjustments can be made, the bounding particulate and water content for and MCO will be recalculated. If the total particulate and associated bound water is less than that presented in Sloughter (2000), fuel cleaning validation will be considered complete.

If these steps are not successful, other actions will be considered, including rerunning the fuel cleaning qualification test using different operating parameters.

The cleanliness inspection team members are selected for their experience and expertise in various SNF disciplines, and as such form a select panel for the purpose of performing the fuel cleanliness assessments. A certified Quality Control Inspector will also be present during cleanliness inspections to verify that recorded data are complete and correct.

Upon completion of the FRS process validation testing, a final report will be prepared describing the PCM performance and validation testing results. This report will form the basis for validating the PCM performance and verifying that canister particulate loading levels in MCOs will not exceed safety basis limits. This FRS Process Validation report will be peer reviewed to satisfy OCRWM documentation requirements. QA review and signoff will be required to confirm that the inspection data have been appropriately documented. Nuclear Safety will also review and approve the final report to corroborate that the inspection results are within the safety basis for MCO fuel loading.

After the process is validated, periodic inspection of sample lots of cleaned fuel will be performed in the production mode. These inspections will verify there has been no degradation of the cleaning process during production operations (Stegen 2000). Cleanliness inspections of the production samples will be the same as those performed on cleaned fuel during process validation testing. Similar data sheets will be used to record damage levels and the results of the cleanliness inspections. These packages of data sheets constitute quality records for the MCO loading inventories, and will also be subjected to peer reviews to satisfy OCRWM documentation requirements. The peer reviews may entail the use of video records generated during the inspection processes. 
HNF-5271, Rev. 1

\subsection{REFERENCES}

Pajunen, A. L., 2000, Phased Startup Initiative Phases 3 and 4 Test Plan and Test Specification (OCRWM), HNF-4898, Rev. 1, Fluor Hanford, Richland, Washington.

Pitner, A. L., 1998, Summary Assessment of Fuel Damage Distributions in the K Basins, HNF2586, Rev 0, DE\&S Hanford, Richland, Washington.

Pitner, A. L., 2000, Engineering Work Plan for Development of Phased Startup Initiative (PSI) Phases 3 and 4 Test Equipment, SNF-6109, Rev. 0, Fluor Hanford, Richland, Washington.

Sloughter, J. P., 2000, Estimates of Particulate Mass in Multi-Canister Overpacks, HNF-1527, Rev 3, Fluor Hanford, Richland, Washington.

Stegen, G. E. and R. A. Sexton, 2000, Fuel Retrieval System Fuel Cleanliness Process Validation Procedure (OCRWM), SNF-3896, Rev. 1, Fluor Hanford, Richland, Washington.

Quality Assurance Program Plan for Implementation of the OCRWM QARD for the Spent Nuclear Fuel Project, QAPP-OCRWM-001, Rev 4, Fluor Daniel Hanford, Richland, Washington.

DOE/RW/0333P, Office of Civilian Radioactive Waste Management Quality Assurance Requirements and Description. 
HNF-5271, Rev. 1

Figure 1. Conical Particulate Pile in Relation to Fuel Assembly-Overall View.

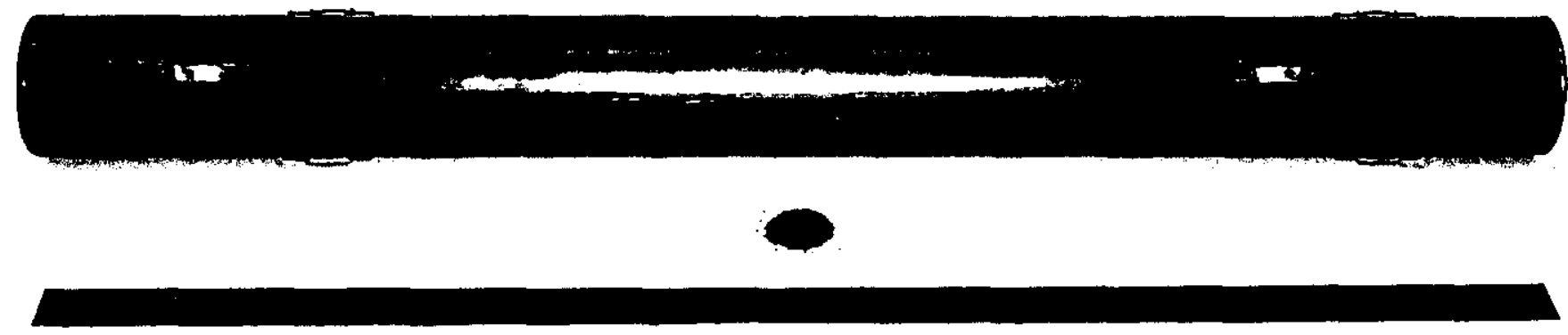

$7 / 27 / 1999$ 


\section{HNF-5271, Rev. 1}

Figure 2. Conical Particulate Pile in Relation to Fuel Assembly-End View.

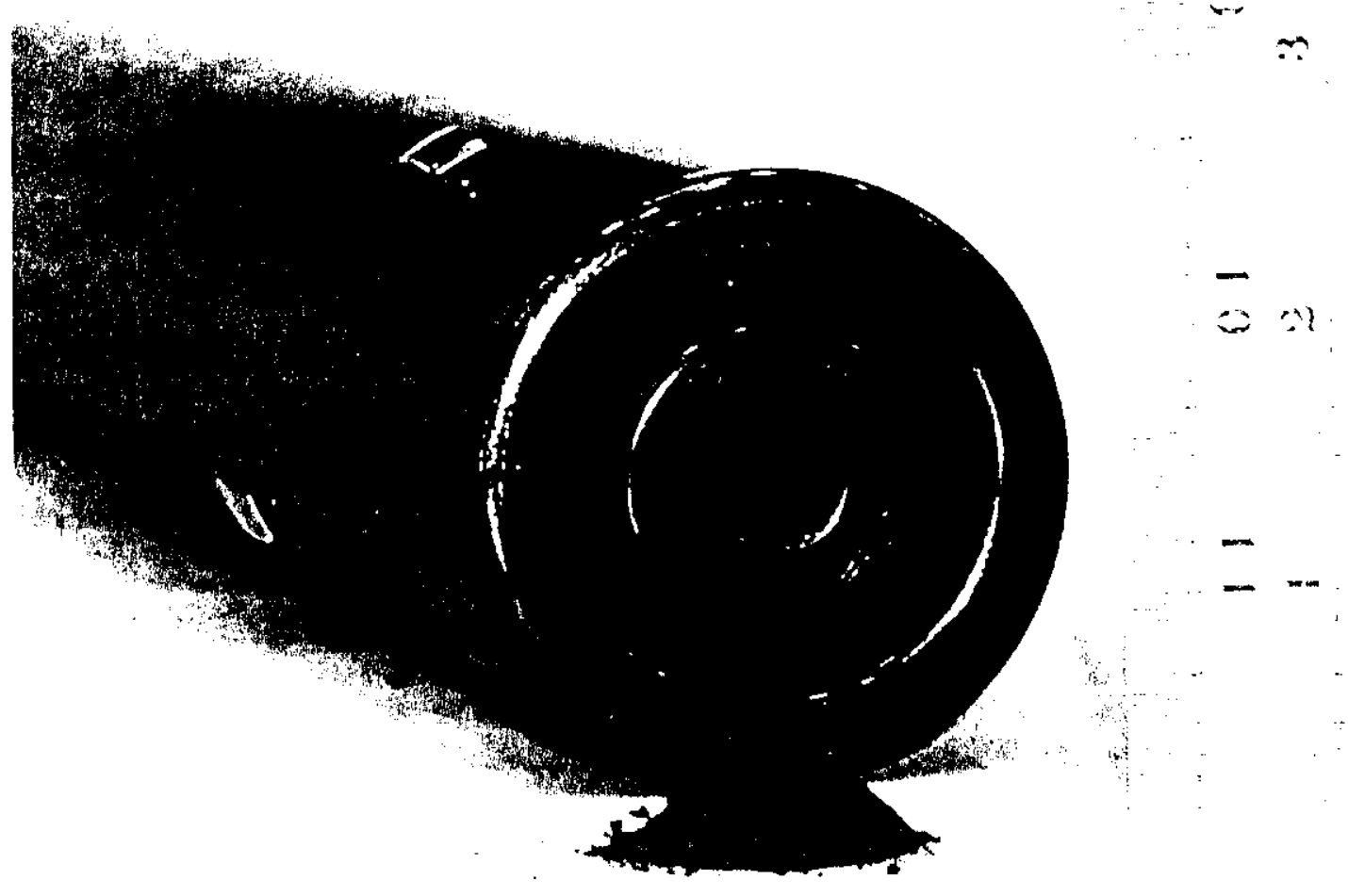


HNF-5271, Rev. 1

Figure 3. Schematic of Canister Sludge Collection Tray.

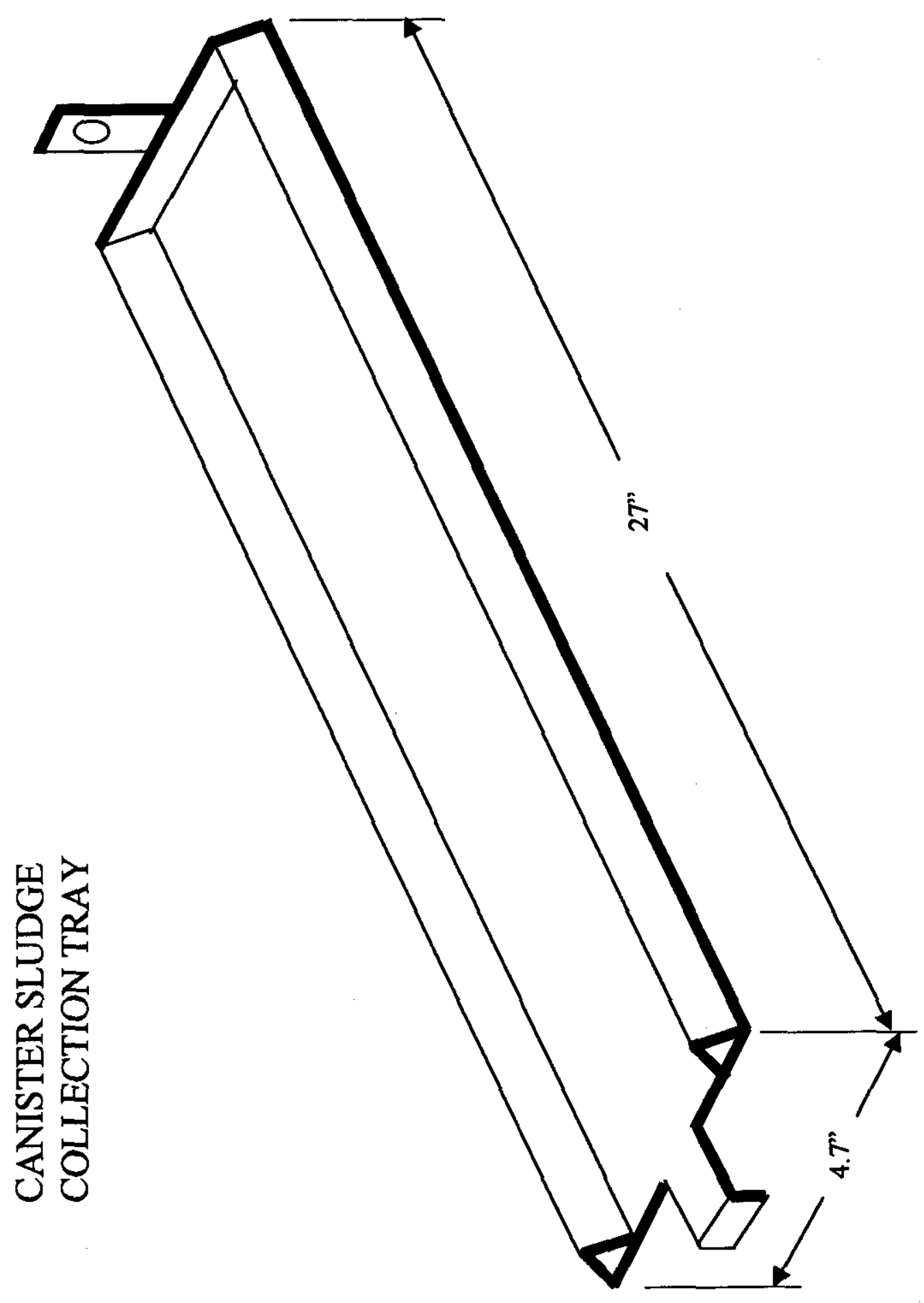


Figure 4. Sludge Pickup Adapter for Particulate Volume Assessment.
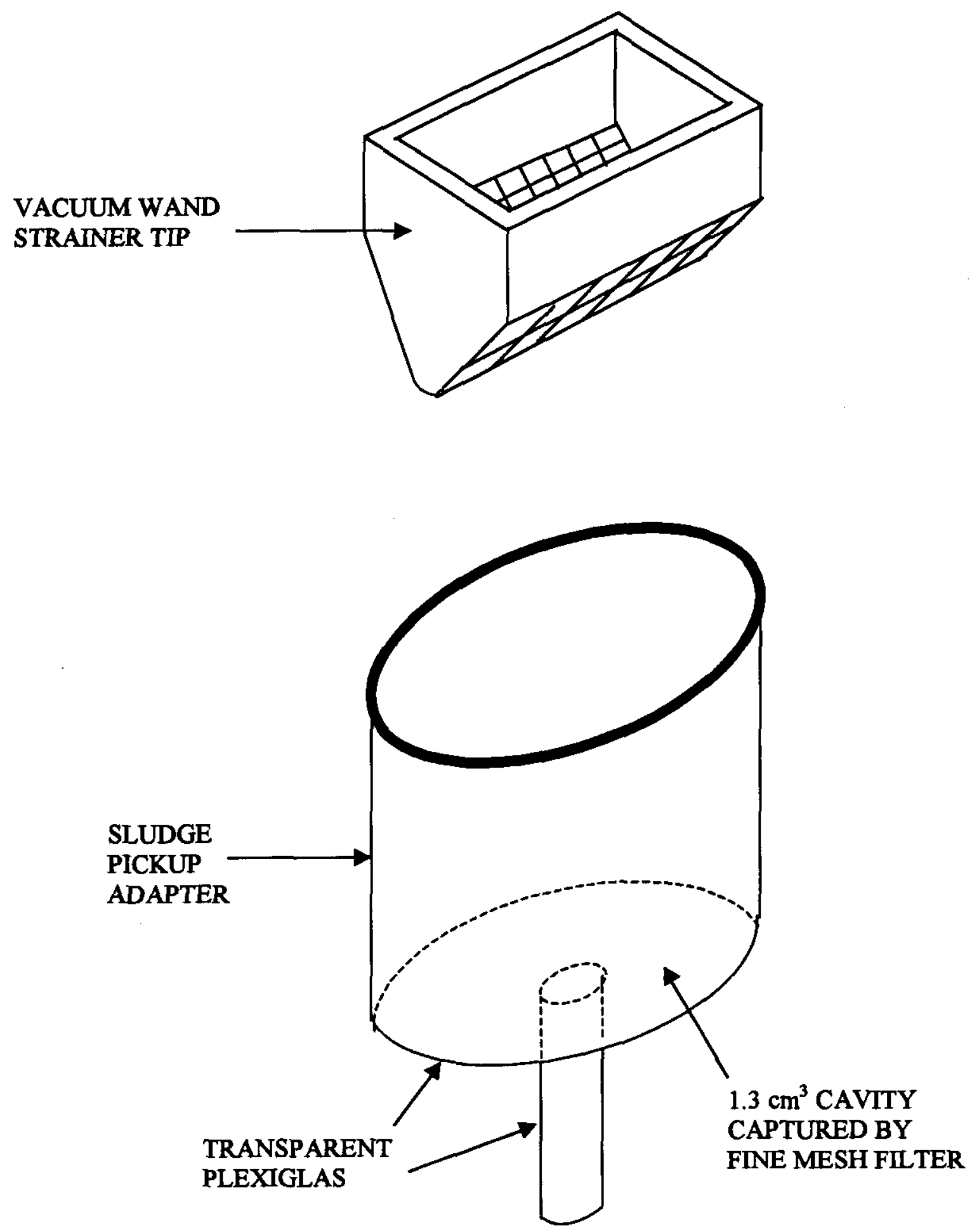


\section{DISTRIBUTION SHEET}

\begin{tabular}{|c|c|c|c|c|c|}
\hline \multirow{2}{*}{$\begin{array}{l}\text { To } \\
\text { Distribution }\end{array}$} & \multirow{2}{*}{\multicolumn{3}{|c|}{$\begin{array}{l}\text { From } \\
\text { Process Engineering }\end{array}$}} & \multicolumn{2}{|l|}{ Page 1 of 1} \\
\hline & & & & \multicolumn{2}{|l|}{ Date $6 / 22 / 00$} \\
\hline \multicolumn{4}{|l|}{ Project Title/Work Order } & \multicolumn{2}{|c|}{ EDT No. N/A } \\
\hline \multicolumn{4}{|c|}{$\begin{array}{l}\text { Planning Document for Spent Nuclear Fuel Cleanliness Inspection Process } \\
\text { (OCRWM) Rev. } 1\end{array}$} & \multicolumn{2}{|c|}{ ECN No. 661450} \\
\hline Name & MSIN & $\begin{array}{c}\text { Text } \\
\text { With All } \\
\text { Attach. }\end{array}$ & $\begin{array}{l}\text { Text } \\
\text { Only }\end{array}$ & $\begin{array}{c}\text { Attach./ } \\
\text { Appendix } \\
\text { Only }\end{array}$ & $\begin{array}{l}\text { EDT/ECN } \\
\text { Only }\end{array}$ \\
\hline
\end{tabular}

Spent Nuclear Fuel Project

R. D. Crowe

G. M. Davis

P. E. Davis

J. A. Dent

J. R. Frederickson

J. C. Gruber

V. L. Hoefer

M. J. Langevin

J. D. Mathews

W. C. Miller

J. W. Neskas

A. L. Pajunen

A. L. Pitner

T. J. Ruane

L. S. Semmens

R. A. Sexton

J. L. Shelor

J. P. Sloughter

D. W. Smith

G. E. Stegen

J. A. Swenson

J. A. Tittle

P. A. Young

SNF Project

SNF Training

$\begin{array}{ll}\text { R3-26 } & \text { X } \\ \text { L6-58 } & \text { X } \\ \text { X3-80 } & \text { X } \\ \text { X3-65 } & \text { X } \\ \text { R3-86 } & \text { X } \\ \text { X3-86 } & \text { X } \\ \text { R3-86 } & \text { X } \\ \text { X4-01 } & \text { X } \\ \text { X3-65 } & \text { X } \\ \text { R3-11 } & \text { X } \\ \text { R3-86 } & \text { X } \\ \text { R3-86 } & \text { X } \\ \text { R3-86 } & \text { X } \\ \text { X3-61 } & \text { X } \\ \text { X3-79 } & \text { X } \\ \text { R3-86 } & \text { X } \\ \text { X4-04 } & \text { X } \\ \text { K9-46 } & \text { X } \\ \text { S2-48 } & \text { X } \\ \text { X24-01 } & \text { X } \\ \text { R3-11 } & \text { X } \\ \text { X3-80 } & \text { X } \\ \text { X3-88 } & \text { X } \\ \text { R3-11 } & \text { X } \\ \text { S2-45 } & \text { X } \\ \text { X3-86 } & \text { X }\end{array}$

SNF Procedures 